\title{
Mild Concentration of Ethanol in Combination with Ascorbic Acid Inhibits Browning and Maintains Quality of Fresh-cut Lotus Root
}

Jia Gao ${ }^{1}$, Yaguang Luo ${ }^{2,3}$, Ellen Turner ${ }^{2,3}$, Yongqing Zhu ${ }^{1}$, 
Abstract

Aqueous solutions of ethanol and ascorbic acid alone and in combination were compared to a commonly used sanitizer, sodium hypochlorite, and a leading commercial antibrowning agent containing calcium ascorbate (CA) for their efficacy to inhibit microbial growth and browning on fresh-cut lotus root. Fresh-cut lotus root slices were immersed in one of 7 treatment solutions including water (control), 30\% ethanol (v/v), 30\% ethanol (v/v) plus $30 \mathrm{~g} \mathrm{~L}^{-1}$ ascorbic acid (AA), $30 \%$ ethanol (v/v) plus $30 \mathrm{~g} \mathrm{~L}^{-1} \mathrm{CA}, 30 \mathrm{~g} \mathrm{~L}^{-1} \mathrm{AA}, 30 \mathrm{~g} \mathrm{~L}^{-1} \mathrm{CA}$ and $100 \mathrm{mg} \mathrm{L}^{-1}$ sodium hypochlorite for $2 \mathrm{~min}$, and then packaged in polyethylene bags and stored for $28 \mathrm{~d}$ at $4{ }^{\circ} \mathrm{C}$. Packages were monitored for headspace gas composition, color, texture, aerobic mesophilic bacteria, and yeast and mold populations, electrolyte leakage and sensory attributes. The results indicate that all ethanol treatments, with and without added AA or CA, not only inhibited microbial growth, but also delayed browning more effectively than either AA or CA alone. The combined treatments of Ethanol 30\% (v/v) along with $30 \mathrm{~g} \mathrm{~L}^{-1} \mathrm{AA}$ or $30 \mathrm{~g} \mathrm{~L}^{-1} \mathrm{CA}$ were even more effective than ethanol alone in maintaining quality of fresh-cut lotus slices during cold storage. Increasing ethanol concentration within the range of 5 to $30 \%(\mathrm{v} / \mathrm{v})$ when accompanied by $30 \mathrm{~g} \mathrm{~L}^{-1} \mathrm{AA}$, decreased microbial populations and had little effect on quality maintenance of fresh-cut lotus root during cold storage. Ethanol concentrations of 20 to $30 \%$ (v/v) in conjunction with $30 \mathrm{~g} \mathrm{~L}^{-1}$ AA have the potential to inhibit browning and maintain quality of fresh-cut lotus root slices for more than $14 \mathrm{~d}$ when stored at $4{ }^{\circ} \mathrm{C}$. This is the first use of ethanol as a dual control for both browning and microbial growth in fresh-cut lotus root.

Key words: fresh-cut lotus root, ethanol, ascorbic acid, anti-browning, antimicrobial, quality 


\section{Introduction}

Lotus root is a popular aquatic root vegetable world-wide because of its sensory attributes and nutritional value (Du et al., 2009; Xing et al., 2010). High levels of potassium, iron, copper, thiamine, riboflavin, pyridoxine, vitamin C, polyphenols and dietary fiber (USDA, 2015) confer many health benefits, such as improving blood circulation, digestion, heart health, mental clarity, mood, and immune function, and reducing anxiety, headache and blood pressure (Mukherjee et al., 2010; Sridhar \& Bhat, 2007). Zhao et al. (2014) identified several alkaloids present in lotus root, which has been used traditionally along with the leaf seed and flower to treat many conditions including small pox, dysentery, cholera, cough, bleeding disorders, sunstroke, dizziness, cancer, hyperdipsia, strangury, vomiting, leprosy, skin diseases, anxiety disorders, and as a poison antidote (Mukherjee et al. , 2009; Sridhar \& Bhat, 2007; Yang et al., 2007). Additionally, lotus root has mucoprotective properties, which are beneficial in the treatment of indigestion and hemorrhoids (Chatterjee \& Pakrashi, 1991; Mukherjee et al., 2009) and antidiabetic and anti-inflammatory properties due to presence of a steroidal triterpenoid (Lee et al., 2001; Mukherjee et al., 2009). Lotus root has also been demonstrated to have anti-obesity, hepatoprotective, antipyretic, antioxidant, antibacterial, antifungal, antidiarrheal, and diuretic activities, as well as sedation effects (Hu \& Skibsted, 2002; Mukherjee et al., 2009; Tsuruta et al., 2011; Yang et al., 2007; You et al., 2014).

Fresh lotus roots, which are harvested from bogs, are highly perishable and brown easily after fresh-cut processing due to increased respiration rate, oxidation by phenol metabolismassociated enzymes and microbial growth in the injured tissues (Ahvenainen, 1996; Hu et al., 2010; Jiang et al., 2014; Zhang et al., 2013). Improving quality and shelf-life of fresh-cut lotus 
root will reduce costs associated with losses and increase demand for this commodity. Browning is the main physiological disorder that results in product losses for fresh-cut lotus root. The enzyme activity that results in browning may additionally destroy some bioactive compounds, reducing the nutritional quality of lotus root. Many treatments have been researched and applied in attempt to inhibit browning and maintain quality of fresh-cut lotus root, including heat in conjunction with anaerobic conditions (Son et al., 2015), carbon monoxide (CO) fumigation (Zhang et al., 2013), hydrogen sulfide $\left(\mathrm{H}_{2} \mathrm{~S}\right)$ fumigation (Sun et al., 2015), chitosan-based coating (Xing et al., 2010), aqueous chlorine dioxide $\left(\mathrm{ClO}_{2}\right)$, ascorbic acid, erythorbic acid, citric acid, $L$-cysteine, $\mathrm{NaHSO}_{3}$ and modified atmosphere (Du et al., 2009; Jiang et al., 2014; Lee \& Eun, 1999).

All of these methods have some drawbacks. Storage of fresh-cut lotus root under anaerobic conditions would cause fermentation to occur in living tissues resulting in an unpleasant odor. Carbon monoxide and $\mathrm{H}_{2} \mathrm{~S}$ are poisonous gases, which are dangerous to work with and those studies were only conducted for seven and ten days, respectively, which may not have been long enough to determine whether the treatments resulted in tissue damage that shortened shelf life. Chitosan-based coating of vegetables is not desirable to consumers maintaining a vegetarian, vegan or kosher diet. Ascorbic acid and citric acid have limited effect as antimicrobials and antibrowning agents and $L$-cysteine imparts a bitter taste to the lotus root. Sodium bisulfite was banned from use on fresh fruit and vegetables in the United States in 1986, because of severe reactions in allergic individuals (U.S. FDA, 1986, 2011). Modified atmosphere packaging (MAP) is not in itself sufficient to prevent browning. 
Ethanol is a potent antimicrobial agent commonly used in medical and biological sterilization of inanimate surfaces. Ethanol is a 'generally recognized as safe' (GRAS) substance, naturally found in plants, and at low concentrations causes little damage in fruit and vegetables (Hu et al., 2010; Janisiewicz \& Conway, 2010). Additionally, several researchers have used ethanol vapors or dips to sanitize plant materials to inhibit decay (Candir et al., 2012; Lichter et al., 2002; Lurie et al., 2006) and growth of microbial populations including Botrytis cinerea (Chervin et al., 2009; Chervin et al., 2005; Karabulut et al., 2004) and E. coli (Pinto et al., 2006) on grapes. Additionally, ethanol treatments have been demonstrated to retard tissue senescence and ripening, inhibit ethylene synthesis and action, decrease spoilage, and reduce chilling injury symptoms in a variety of fruit and vegetables including mango (Gutiérrez-Martínez et al., 2012; Plotto et al., 2006), apple (Bai et al., 2004), sweet cherry (Bai et al. , 2011), oriental sweet melon (Liu et al., 2012), asparagus (Herppich et al., 2014), eggplant (Hu et al., 2010), and sunchoke (Wang et al., 2014). Ascorbic acid has been reported to effectively control enzymatic browning of fruit and vegetables (Du et al., 2009; Lee \& Eun, 1999; Son et al., 2015). In our previous research we discovered that ethanol at low concentrations was able to control browning in apple slices. However, the use of ethanol to maintain microbiological and sensorial quality in fresh-cut lotus root is unknown. The objective of this study was to assess the effectiveness of low concentrations of ethanol in combination with other anti-browning agents and MAP to maintain color, texture, tissue integrity, and sensory attributes of and suppress microbial growth on freshcut lotus root slices stored at $4{ }^{\circ} \mathrm{C}$. 


\section{Materials and methods}

\subsection{Plant material}

Lotus roots (Nelumbo nucifera Gaertn.) were purchased from a grocery store in Silver Spring, MD, USA, transported to the laboratory and stored at $4{ }^{\circ} \mathrm{C}$ overnight, before processing. Samples were selected for uniformity of size and color, and absence of mechanical damage. Whole lotus roots were rinsed with tap water to remove soil and washed with sodium hypochlorite $(\mathrm{NaOCl})$ solution (100 mg L $\mathrm{m}^{-1}$ free chlorine, $\mathrm{pH}$ 6.5), which was prepared using Clorox (6 \% (v/v) sodium hypochlorite, Clorox Co., Oakland, CA) and the $\mathrm{pH}$ was adjusted using citric acid solution. Lotus roots were hand peeled, in one direction using a manual peeler to remove a minimal amount of surface tissue and then sliced $5 \mathrm{~mm}$ thick using a meat slicer (Berkel, Italy).

\subsection{Experiment 1: Assess efficacy of $30 \%$ ethanol treatments to inhibit browning and microbial} growth of fresh-cut lotus root

Seven wash treatments were prepared with deionized water including: 1) non-chlorinated water, 2) $30 \%$ (v/v) ethanol (E), 3) $30 \mathrm{~g} \mathrm{~L}^{-1}$ ascorbic acid (AA), 4) $30 \mathrm{~g} \mathrm{~L}^{-1}$ NatureSeal $\AA$ antibrowning agent with sole ingredient calcium ascorbate (CA) (NatureSeal Inc., USA), 5) 30 \% E $+30 \mathrm{~g} \mathrm{~L}^{-1} \mathrm{CA}$, 6) $\left.30 \% \mathrm{E}+30 \mathrm{~g} \mathrm{~L}^{-1} \mathrm{AA}, 7\right)$ sodium hypochlorite $(\mathrm{NaOCl})$ wash solution (100 mg $\mathrm{L}^{-1}$ free chlorine, $\left.\mathrm{pH} 6.5\right)$. Fresh-cut lotus root slices $(3.4 \mathrm{~kg})$ were submerged and manually agitated in $3 \mathrm{~L}$ of one of the 7 treatment solutions for $2 \mathrm{~min}$. Washed samples $(100 \pm 2.0 \mathrm{~g})$ for each treatment were packaged in polyethylene bags $(22.5 \mathrm{~cm} \times 17 \mathrm{~cm}$, Pacific Southwest Container Inc., Modesto, CA, USA) with film oxygen transmission rate (OTR) of $21.4 \mathrm{pmol} \mathrm{s}^{-1}$ $\mathrm{m}^{-2} \mathrm{~Pa}^{-1}$ and stored at $4{ }^{\circ} \mathrm{C}$. Package atmospheres, color, texture and microbial analyses were 
performed on days $1,7,14,21,28$. Tissue electrolyte leakage and sensory evaluation were performed on day 28 .

\subsection{Experiment 2: Effect of ethanol concentration}

Lower concentrations of ethanol combined with ascorbic acid including: $5 \% \mathrm{E}+30 \mathrm{~g} \mathrm{~L}^{-1} \mathrm{AA}$, $10 \% \mathrm{E}+30 \mathrm{~g} \mathrm{~L}^{-1} \mathrm{AA}, 20 \% \mathrm{E}+30 \mathrm{~g} \mathrm{~L}^{-1} \mathrm{AA}$, and $25 \% \mathrm{E}+30 \mathrm{~g} \mathrm{~L}^{-1} \mathrm{AA}$, were tested alongside $30 \% \mathrm{E}+30 \mathrm{gL}^{-1} \mathrm{AA}$ to determine whether they could inhibit browning and maintain quality of fresh-cut lotus root slices. Other than the wash treatments, all the processing steps were kept the same as in experiment 1. Package atmosphere, color and microbial analyses were performed on days 1,7 , and 14 .

\subsection{Quality evaluation}

\subsubsection{Package headspace gas composition}

The package atmospheres were measured immediately upon removal of the samples from storage. Gas samples were withdrawn from the package by inserting the needle of a measuring assembly through a septum adhered to the packaging film and $\mathrm{O}_{2}$ and $\mathrm{CO}_{2}$ concentrations were determined using a gas analyzer (Check mate II, PBI Dansensor Co., Denmark).

\subsubsection{Color assessment}

The surface color of samples was measured with a colorimeter (Konica Minolta CR-400 Chroma Meter, Ramsey, NJ, USA). The instrument was calibrated with a white tile (Y= $94.0, \mathrm{x}=0.3130$ and $\mathrm{y}=0.3191)$. Measurements were taken for $L^{*}, a^{*}$ and $b^{*}$ values at 2 sites on each of 20 lotus slices for each treatment group. Color coordinates, $a^{*}$ and $b^{*}$, were converted into hue angles $\left[\right.$ hue $\left.=\tan ^{-1}(b / a)\right]$. 


\subsubsection{Texture analysis}

Texture properties of the samples were assessed using a TA-XT2i texture analyzer (Texture Technologies Corp., Scarsdale, NY, USA) with the following parameters: load cell $=30 \mathrm{~kg}$, probe $=4 \mathrm{~mm}$ diameter aluminum cylinder and test speed $=2 \mathrm{~mm} \mathrm{~s}^{-1}$. The firmness was defined as the maximum force needed to puncture the lotus root slices to a depth of 3.5 $\mathrm{mm}$. Measurements were performed at 2 sites in the cortex of each fresh-cut lotus root slice. For each treatment, 5 slices were measured for each of 3-5 replicates.

\subsubsection{Electrolyte leakage analysis}

Tissue electrolyte leakage was measured following a modified procedure (Wang, Feng et

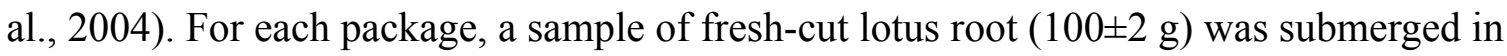
$300 \mathrm{~mL}$ of deionized water for $30 \mathrm{~min}$ at $22^{\circ} \mathrm{C}$. The electrolyte content of the solution was determined by measuring the electrical conductivity with a conductivity meter (model 135A, Orion Research, Inc., Beverly, MA, USA). Total electrolytes of the fresh-cut lotus root samples were determined after repeatedly freezing at $-20{ }^{\circ} \mathrm{C}$ for $24 \mathrm{~h}$ and thawing at room temperature. Relative electrical conductivity (REC) was expressed as a ratio of fresh over total electrolytes.

\subsubsection{Sensory evaluation}

A six-member trained sensory panel conducted the visual and olfactory evaluation of the fresh-cut lotus root samples stored for 28 days. Overall visual quality was assessed with a 9point hedonic scale where $9=$ like extremely, $7=$ like moderately, $5=$ neither like nor dislike, 3 = dislike moderately, 1 = dislike extremely (Bai et al., 2004). Off-odor was evaluated on a scale of 1 to 5 , where $1=$ none, $3=$ moderate and $5=$ severe (Kou et al., 
2014b). The samples were coded with a random three-digit number to mask the treatment identity, in order to minimize subjectivity and were compared with freshly prepared samples.

\subsection{Microbial assays}

Microbial growth on the fresh-cut lotus root slices was assessed during each evaluation day. Each $25 \pm 0.5 \mathrm{~g}$ sample was blended with $100 \mathrm{~mL}$ of sterile phosphate buffered saline (PBS, Fisher Scientific, Pittsburgh, PA, USA) using a stomacher bender (Model 80, Seward Medical, London, UK) for $2 \mathrm{~min}$. The filtrate and its appropriate dilutions were logarithmically spread on agar plates with a Whitley automatic spiral plater (Wasp II, Don Whitley Scientific Ltd., West Yorkshire, UK). The aerobic mesophilic bacterial (AMB) population was determined by plating samples on tryptic soy agar (TSA, Difco, Detroit, MI, USA) and incubating at $28^{\circ} \mathrm{C}$. Yeast and mold (Y\&M) enumeration was performed by plating on potato dextrose agar (PDA, Difco, Detroit, MI, USA) supplemented with $200 \mathrm{mg} \mathrm{L}^{-1}$ chloramphenicol (Sigma-Aldrich, St Louis, $\mathrm{MO})$ and incubating at room temperature $\left(22^{\circ} \mathrm{C}\right)$. Microbial colonies were counted using a

ProtoCOL automated colony counter (Synbiosis, Cambridge, UK) and reported as log CFU/g of tissue.

\subsection{Statistical analysis}

Package atmospheres, color, texture, and microbial enumeration data were analyzed as twofactor (treatment and storage duration) linear models using the PROC MIXED procedure (SAS Institute Inc 1999, Cary, NC). Assumptions of normality and variance homogeneity of the mixed model were checked and the variance grouping technique was used to correct for variance heterogeneity. When effects were statistically significant, means were compared using Sidak 
adjusted $p$-values to maintain experiment-wise error $\leq 0.05$. For electrolyte leakage (REC) and sensory data, treatment differences were tested with Tukey-Kramer test, $\alpha=0.05$. Analysis of Variance and Pearson correlation analysis (SAS Version 9.2, SAS Institute, Inc.) were used to generate regression models and cross correlate among parameters: $\mathrm{CO}_{2}, \mathrm{O}_{2}$, Peak force, $\mathrm{AMB}$, $\mathrm{Y} \& \mathrm{M}, L^{*}$ value, hue angle, REC, off-odor and overall visual quality The data was reported as the mean of 3-5 replicates \pm standard error (SE).

\section{Results and Discussion}

\subsection{Experiment 1: Assess efficacy of 30\% ethanol treatments for inhibition of browning and} microbial growth

\subsubsection{Package headspace gas composition}

Headspace gas composition is an indication of the product's respiration rate (Kou et al., 2014a). Lower oxygen and higher carbon dioxide indicate a higher respiration rate which tends to accelerate quality degradation and shorten shelf life. 
Fig. 1. Evolution of $\mathrm{O}_{2}$ and $\mathrm{CO}_{2}$ plotted as a function of storage time for fresh-cut lotus root slices (experiment 1). Data represent the mean \pm S.E. $(n=4)$.

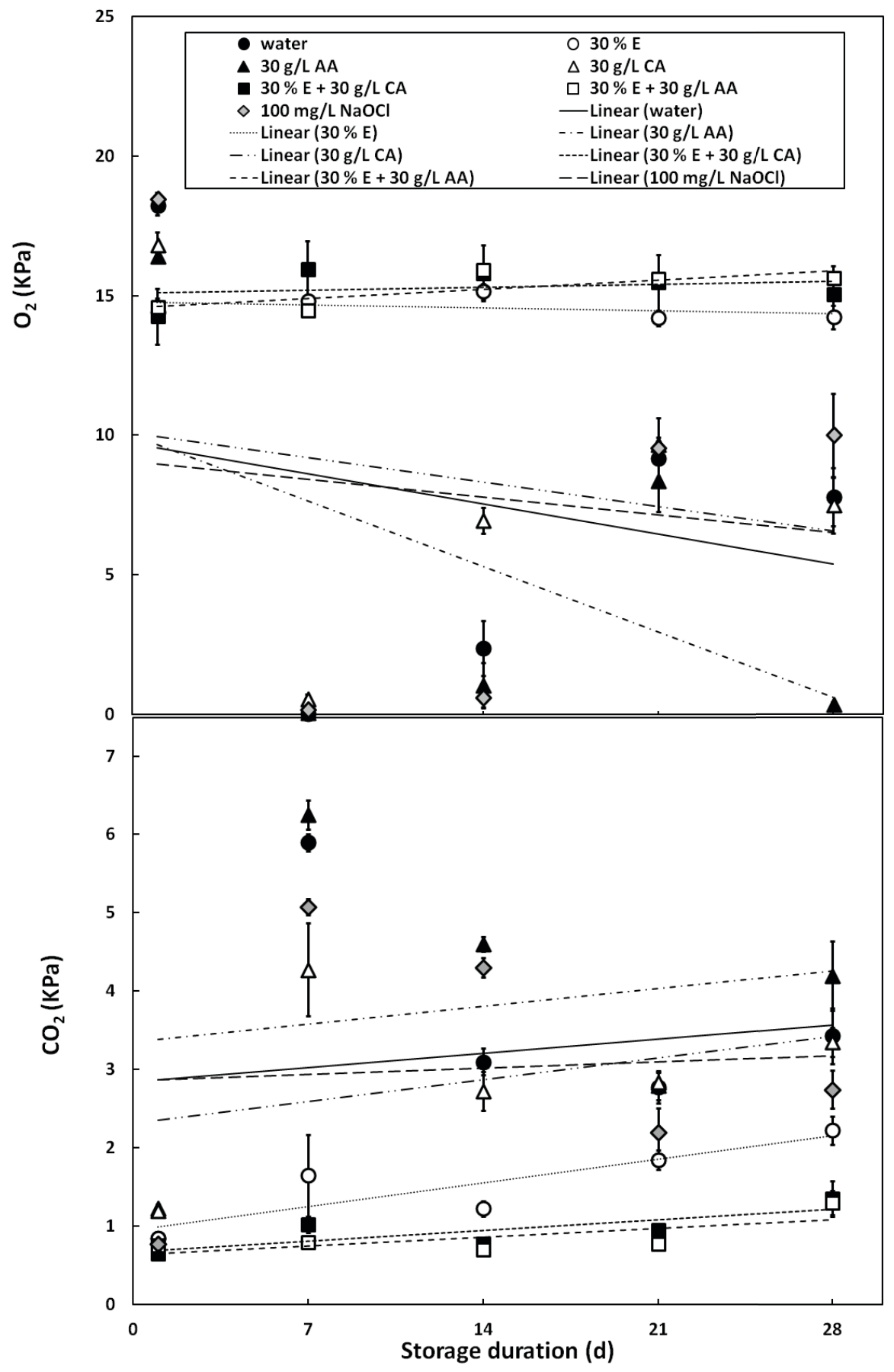


Figure 1 shows the changes in $\mathrm{O}_{2}$ and $\mathrm{CO}_{2}$ partial pressures of fresh-cut lotus root slices stored at $4{ }^{\circ} \mathrm{C}$ for $28 \mathrm{~d}$. There was no significant difference in gas atmospheres among water wash, $30 \mathrm{~g}$ $\mathrm{L}^{-1} \mathrm{CA}$ and $\mathrm{NaOCl}$ treatments during storage, while $\mathrm{O}_{2}$ and $\mathrm{CO}_{2}$ partial pressures for $30 \mathrm{~g} \mathrm{~L}^{-1} \mathrm{AA}$ treatment had a sharper decline and increase, respectively, during the last week of storage $(\mathrm{P}<0$. 01). The $\mathrm{O}_{2}$ partial pressure in treatments without ethanol declined sharply during the first $7 \mathrm{~d}$ (from $14.25-18.45 \mathrm{kPa}$ to $0.02-0.53 \mathrm{kPa}$ ), then rose again slowly, but after $21 \mathrm{~d}$ declined again for some treatments. Conversely, the $\mathrm{CO}_{2}$ partial pressure in treatments without ethanol increased sharply during the first $7 \mathrm{~d}$ (from $0.65-1.23 \mathrm{kPa}$ to $4.28-6.25 \mathrm{kPa}$ ), then declined over the next 14 $\mathrm{d}$, rising again during the last $7 \mathrm{~d}$ of storage. This pattern suggests that the samples of the four non-ethanol treatment groups had a high respiration rate and thus consumed the $\mathrm{O}_{2}$ and produced a high concentration of $\mathrm{CO}_{2}$ in the package during the first week after processing. There were no significant differences in $\mathrm{O}_{2}$ or $\mathrm{CO}_{2}$ partial pressures between $30 \% \mathrm{E}+30 \mathrm{~g} \mathrm{~L}^{-1} \mathrm{AA}$ and $30 \% \mathrm{E}+$ $30 \mathrm{~g} \mathrm{~L}^{-1} \mathrm{CA}$ treatments during storage, but these 2 treatments had significantly higher and lower $\mathrm{O}_{2}$ and $\mathrm{CO}_{2}$ partial pressures, respectively, than other treatments $(P<0.01)$. Partial pressures of $\mathrm{O}_{2}$ and $\mathrm{CO}_{2}$ for $30 \% \mathrm{E}$ treatment were next highest and lowest, respectively. Sample packages for treatments containing ethanol maintained $\mathrm{O}_{2}(14.20-15.95 \mathrm{kPa})$ and $\mathrm{CO}_{2}(0.65-2.23 \mathrm{kPa})$ partial pressures at more nearly a steady state than those of other treatments, which indicated a reduced respiration rate in these samples. Wang, Nie and Cantwell (2014) also observed significantly depressed respiration rate in sunchoke tuber slices treated with ethanol. Other researchers have noted reduced respiration rates in ethanol treated apple (Bai et al., 2004), eggplant slices (Hu et al., 2010), and broccoli florets (Asoda et al., 2009). Since ethanol treatment reduced microbial growth in all these instances, the reduced respiration rate may be attributable to the lower 
microbial populations. However, ethanol has been shown to inhibit mitochondrial function and enzyme activity (Kern et al., 2009) and this is more likely to be the cause of the lower respiration rates observed in packages of ethanol treated lotus root slices.

\subsubsection{Color changes}

Color is the basis for sorting lotus root slices into commercial grades (Siomos et al., 2010; Xing et al., 2010). For fresh-cut lotus root slices, a lower $\mathrm{L}^{*}$ value indicates tissue darkening, increase in $\mathrm{a}^{*}$ value indicates increase in red/orange tissue discoloration and a greater hue angle indicates tissue color change from pale to red/brown (Plotto et al., 2006). 
Fig. 2. Color changes of fresh-cut lotus root slices expressed as changes in $L^{*}, a^{*}$ and hue angle values during storage at $4{ }^{\circ} \mathrm{C}$ (experiment 1). Data represent the mean \pm S.E. $(\mathrm{n}=4)$.

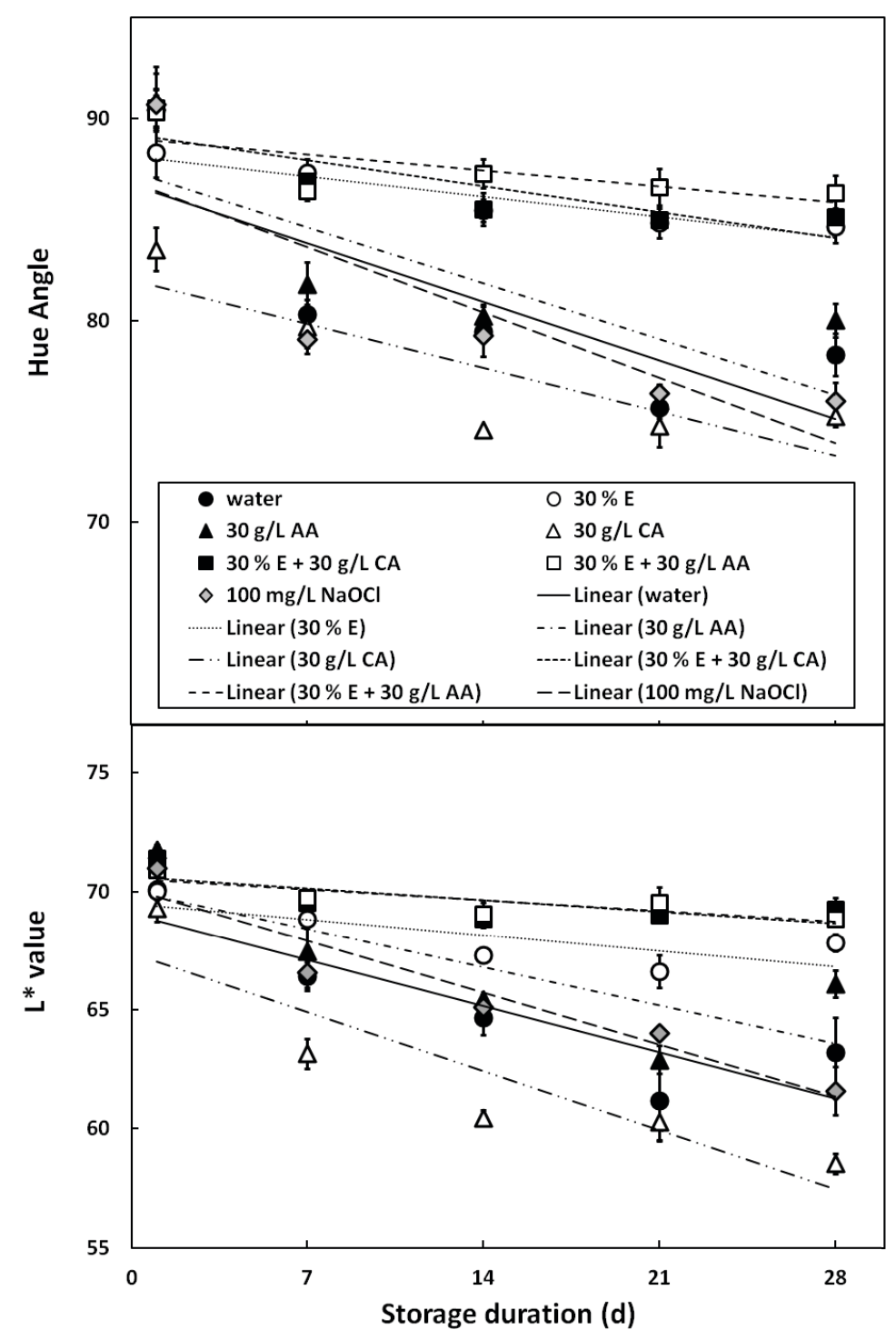

Values for $L^{*}$ and hue angle decreased with increasing storage time (Fig. 2), while $a^{*}$ value increased (Data not shown). Samples treated with $30 \% \mathrm{E}+30 \mathrm{~g} \mathrm{~L}^{-1} \mathrm{AA}$ and $30 \% \mathrm{E}+30 \mathrm{~g} \mathrm{~L}^{-1}$ CA had the least change in $L^{*}$ value, hue angle and $a^{*}$ value from the initial fresh value and therefore the least browning. Samples treated with $30 \% \mathrm{E}$ only had the second least change. 
These preceded $30 \mathrm{~g} \mathrm{~L}^{-1} \mathrm{AA}$ only, followed by water wash control and $\mathrm{NaOCl}$, and $30 \mathrm{~g} \mathrm{~L}^{-1} \mathrm{CA}$ alone had the strongest browning. Samples treated with $30 \% \mathrm{E}+30 \mathrm{~g} \mathrm{~L}^{-1} \mathrm{AA}$ and $30 \% \mathrm{E}+30 \mathrm{~g}$ $\mathrm{L}^{-1} \mathrm{CA}$ did not differ significantly in their $L^{*}$ values or $a^{*}$ values and had only slightly lower $a^{*}$ values than $30 \% \mathrm{E}$ treatment. Color values for these two treatments did not change significantly over time, from day 7 until the end of storage $(P<0.01)$. The hue angle for $30 \% \mathrm{E}+3 \% \mathrm{AA}$ was significantly higher than that for $30 \% \mathrm{E}+30 \mathrm{~g} \mathrm{~L}^{-1} \mathrm{CA}$ and for $30 \% \mathrm{E}(P<0.01)$. There was no significant difference between the hue angle for $30 \% \mathrm{E}+30 \mathrm{~g} \mathrm{~L}^{-1} \mathrm{CA}$ and for $30 \% \mathrm{E}$ alone. Water treatment, $100 \mathrm{mg} \mathrm{L}^{-1} \mathrm{NaOCl}$ solution and $30 \mathrm{~g} \mathrm{~L}^{-1} \mathrm{AA}$ treatments had similar $L^{*}$, hue angle and $a^{*}$ values, all with large change over time, while $3 \% \mathrm{CA}$ had lower $L^{*}$ value and hue angle and higher $a^{*}$ value even than water for the entire storage duration $(P<0.01)$, indicating that this treatment is not suitable for lotus root slices and might exacerbate browning. In this study, samples treated with ethanol maintained desirable gas composition and pale color during the 28 day storage period, but for samples treated without ethanol, gas composition and color changed greatly (Fig. 1 \& Fig. 2). Samples treated with $30 \% \mathrm{E}+30 \mathrm{~g} \mathrm{~L}^{-1} \mathrm{AA}$ and $30 \% \mathrm{E}+30 \mathrm{~g}$ $\mathrm{L}^{-1} \mathrm{CA}$ maintained more stable $L^{*}$ values throughout storage than those in other treatment groups. These values maintained greater stability than those reported by other researchers who attempted to inhibit browning in fresh-cut lotus root (Du et al., 2009; Sun et al., 2015; Xing et al., 2010; Zhang et al., 2013). The efficacy of ethanol to maintain light color of lotus root slices is most likely due to the effect of ethanol on inhibiting the PPO enzyme. Reduced respiration rate and high $\mathrm{O}_{2}$ and low $\mathrm{CO}_{2}$ partial pressures in packages of fresh-cut lotus root could increase browning as a result of greater oxidation. However, the effect of ethanol on suppressing enzyme activity is consistent with reports of its retarding effects on respiration rate (through inhibiting 
mitochondrial function), ethylene synthesis, ripening and senescence (Bai et al., 2004, 2011; Hu et al., 2010; Suzuki et al., 2004, 2005; Wang et al., 2014). Wang et al. (2014) found that ethanol fumigation or dipping treatment significantly delayed and reduced the respiration peak, and delayed the red discoloration of fresh-cut tubers, similar to our results (Fig.1 \& Fig. 2). Color data indicated that inhibition of browning and reddening was dependent on ethanol concentration and treatment time (Fig. 6).

\subsubsection{Texture analysis}

Crispness is one of the important organoleptic quality attributes of fresh lotus root (Dong et al., 2013). The texture data generally shows a trend of declining firmness over time (Fig. 3).

Fig. 3. Firmness measurements of fresh-cut lotus root slices (experiment 1). Data represent the mean \pm S.E. for maximum force $(n=3-5)$.

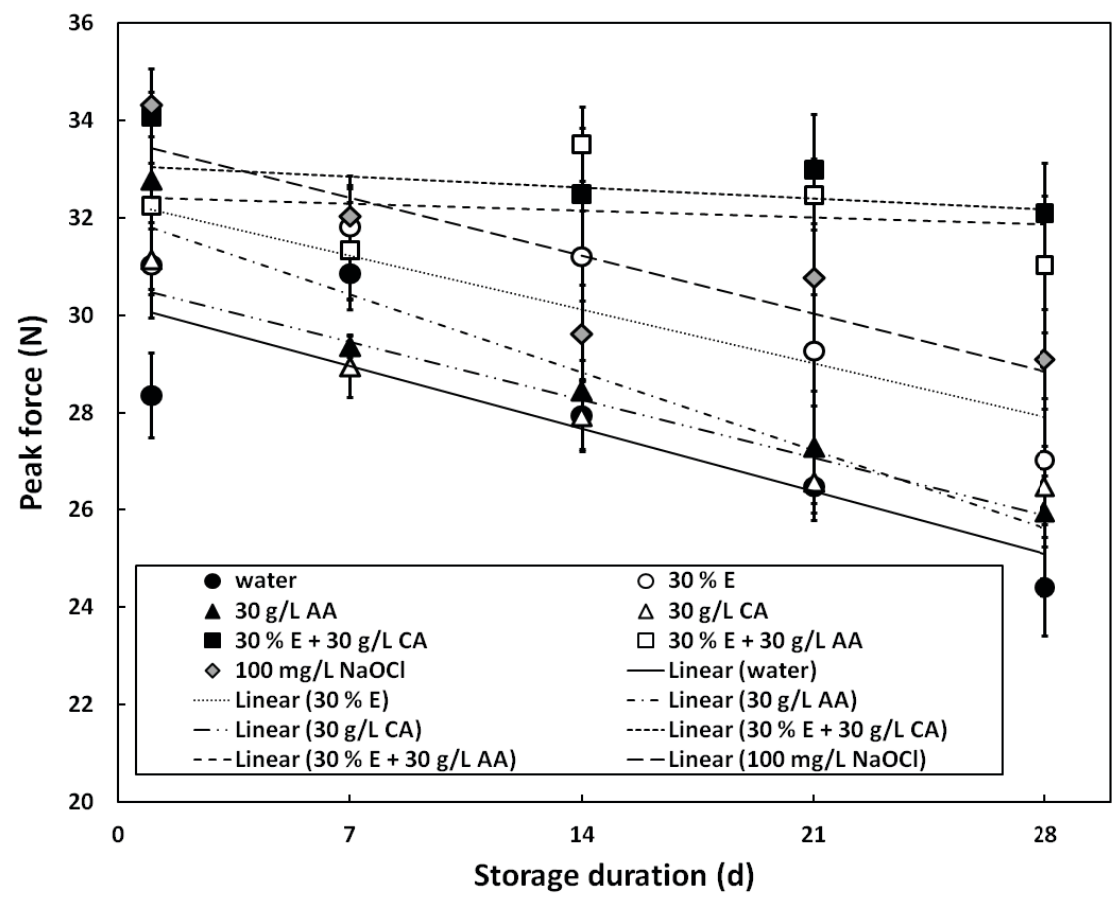


Firmness values for $30 \% \mathrm{E}+30 \mathrm{~g} \mathrm{~L}^{-1} \mathrm{AA}$ and $30 \% \mathrm{E}+30 \mathrm{~g} \mathrm{~L}^{-1} \mathrm{CA}$ treatment groups were not significantly different from each other during the entire storage duration and were higher than for other treatments. These treatment groups were followed in firmness by $100 \mathrm{mg} \mathrm{L}^{-1}$ chlorine and $30 \% \mathrm{E}(P<0.01)$. The lowest firmness values were measured for samples treated with water, $30 \mathrm{~g} \mathrm{~L}^{-1} \mathrm{CA}$ and $30 \mathrm{~g} \mathrm{~L}^{-1} \mathrm{AA}$ with values for the $30 \mathrm{~g} \mathrm{~L}^{-1} \mathrm{AA}$ treatment group showing the steepest decline over time. There was large sample variation among the texture data. Similar to the research of Bai et al. (2004, 2011), ethanol was found to have some positive effect on maintaining firmness (Fig. 3). It may reduce the activity of cell wall degrading enzymes such as polygalacturonase (PG), cellulase, endoglucanase $(\mathrm{Cx}), \beta$-galactosidase $(\beta-\mathrm{GAL})$ and 1 aminocyclopropane-1-carboxylate oxidase (ACC oxidase) (Bai et al., 2011; Pesis et al., 1998; Plotto et al., 2006). However, based on the electrolyte leakage data, ethanol may have resulted in membrane degradation and its effect on firmness may be the result of tissue dehydration. Both AA and CA in combination with ethanol improved firmness and decreased electrolyte leakage compared to ethanol only treatment suggesting a role for AA in alleviating tissue injury.

\subsubsection{Electrolyte leakage analysis}

Table 1 shows the percent electrolyte leakage values for the fresh-cut lotus root slices after $28 \mathrm{~d}$ storage. Samples treated with ethanol and ethanol combinations had significantly higher relative electrical conductivities $(\mathrm{REC})$ than others $(\mathrm{p}<0.05)$ indicating that the ethanol may cause some tissue damage. Samples treated with $30 \% \mathrm{E}$ had the highest REC values (16.01\%), followed by $30 \% \mathrm{E}+30 \mathrm{~g} \mathrm{~L}^{-1} \mathrm{AA}$ treatment $(12.85 \%)$ and $30 \% \mathrm{E}+30 \mathrm{~g} \mathrm{~L}^{-1} \mathrm{CA}$ treatment (12.44 \%). 
Table 1. Electrolyte leakage expressed as the ratio of fresh conductivity over total conductivity for the same sample after repeated freezing and thawing (n-5).

\begin{tabular}{llll}
\hline Treatment & Visual Quality (1-9) & Off Odor (0-5) & Purchase Intent (1-5) \\
\hline water & $3.17 \pm 0.79 \mathrm{~b}$ & $3.27 \pm 0.54 \mathrm{~b}$ & $1.93 \pm 0.04 \mathrm{~b}$ \\
$30 \% \mathrm{E}$ & $4.03 \pm 0.57 \mathrm{~b}$ & $4.20 \pm 0.34 \mathrm{a}$ & $2.53 \pm 0.03 \mathrm{~b}$ \\
$30 \mathrm{~g} \mathrm{~L}^{-1} \mathrm{AA}$ & $3.77 \pm 0.91 \mathrm{~b}$ & $3.33 \pm 0.57 \mathrm{~b}$ & $2.20 \pm 0.04 \mathrm{~b}$ \\
$30 \mathrm{~g} \mathrm{~L}^{-1} \mathrm{CA}$ & $3.20 \pm 0.83 \mathrm{~b}$ & $3.40 \pm 0.56 \mathrm{~b}$ & $2.00 \pm 0.04 \mathrm{~b}$ \\
$30 \% \mathrm{E}+30 \mathrm{~g} \mathrm{~L}^{-1} \mathrm{CA}$ & $6.67 \pm 0.66 \mathrm{a}$ & $3.67 \pm 0.38 \mathrm{ab}$ & $4.07 \pm 0.03 \mathrm{a}$ \\
$30 \% \mathrm{E}+30 \mathrm{~g} \mathrm{~L}^{-1} \mathrm{AA}$ & $6.50 \pm 0.73 \mathrm{a}$ & $3.40 \pm 0.48 \mathrm{~b}$ & $3.87 \pm 0.04 \mathrm{a}$ \\
$100 \mathrm{mg} \mathrm{L}^{-1} \mathrm{NaOCl}$ & $4.03 \pm 0.67 \mathrm{~b}$ & $3.30 \pm 0.51 \mathrm{~b}$ & $2.50 \pm 0.04 \mathrm{~b}$ \\
\hline
\end{tabular}

Values followed by a common letter are not significantly different $(\mathrm{P}>0.05)$.

High ethanol in vegetable or fruit tissue may cause accumulation of ethyl esters which degrade the plasma membrane, increasing ion leakage (Bai et al., 2011; Suzuki et al., 2005). In our research, the electrical conductivity for ethanol-containing treatments was higher than for noethanol treatments (Table 1). Electrolyte leakage results suggest that $30 \%$ ethanol treatments may lead to cell membrane degradation. The added ascorbic acid and calcium ascorbate may have reduced the severity of the tissue damage caused by the ethanol.

\subsubsection{Sensory evaluation}

Table 2 shows the sensory evaluation scores for overall visual quality, off-odor and purchase intent for the fresh-cut lotus root slices after $28 \mathrm{~d}$ storage. Samples from all treatment 
groups had off-odor after $28 \mathrm{~d}$ storage. An alcohol off-odor was detected upon opening samples treated with $30 \% \mathrm{E}, 30 \mathrm{~g} \mathrm{~L}^{-1} \mathrm{CA}, 30 \% \mathrm{E}+30 \mathrm{~g} \mathrm{~L}^{-1} \mathrm{CA}$ and $30 \% \mathrm{E}+30 \mathrm{~g} \mathrm{~L}^{-1} \mathrm{AA}$. However, these samples had less decay smell. Overall visual quality for $30 \% \mathrm{E}+30 \mathrm{~g} \mathrm{~L}^{-1} \mathrm{CA}$ and $30 \% \mathrm{E}$ $+30 \mathrm{~g} \mathrm{~L}^{-1} \mathrm{AA}$ treatment groups and purchase intent scores were significantly higher than the scores for other treatment groups $(\mathrm{p}<0.05)$, and above 6.0 and 3.0, the limits for salability for visual quality and purchase intent, respectively, while other treatment groups were not salable.

Table 2. Visual quality, off odor, and purchase intent scores for fresh cut lotus root slices evaluated by 6 trained panelists on day $28(n=5)$.

\begin{tabular}{cc}
\hline treatment & Relative Electrical Conductivity (\%) \\
\hline water & $5.48 \pm 0.46 \mathrm{c}$ \\
$30 \% \mathrm{E}$ & $16.01 \pm 0.48 \mathrm{a}$ \\
$30 \mathrm{~g} \mathrm{~L}^{-1} \mathrm{AA}$ & $4.61 \pm 0.45 \mathrm{c}$ \\
$30 \mathrm{~g} \mathrm{~L}^{-1} \mathrm{CA}$ & $5.55 \pm 0.32 \mathrm{c}$ \\
$30 \% \mathrm{E}+30 \mathrm{~g} \mathrm{~L}^{-1} \mathrm{CA}$ & $12.44 \pm 0.30 \mathrm{~b}$ \\
$30 \% \mathrm{E}+30 \mathrm{~g} \mathrm{~L}^{-1} \mathrm{AA}$ & $12.85 \pm 0.23 \mathrm{~b}$ \\
$100 \mathrm{mg} \mathrm{L}^{-1} \mathrm{NaOCl}$ & $3.92 \pm 0.26 \mathrm{c}$ \\
\hline
\end{tabular}


Values followed by a common letter are not significantly different $(\mathrm{P}>0.05)$.

In conclusion, $30 \% \mathrm{E}+30 \mathrm{~g} \mathrm{~L}^{-1} \mathrm{CA}$ and $30 \% \mathrm{E}+30 \mathrm{~g} \mathrm{~L}^{-1} \mathrm{AA}$ treatments can maintain the quality of fresh-cut lotus root, but samples treated in these solutions do have residual alcohol smell, although not as strong as those treated in $30 \% \mathrm{E}$ alone. However, upon opening of the bag, the odor soon dissipated so that no direct off-odor due to ethanol remained. Other researchers also reported ethanol off-odor in ethanol-treated fruit and fresh-cut produce when opening sealed packages (Bai et al., 2004, 2011; Plotto et al., 2006).

\subsubsection{Microbial assays}

Figure 4 shows an increase in microbial counts for all treatments over the storage period, with the exception of yeast and mold (Y\&M) for $30 \%$ ethanol which did not change significantly.

Fig. 4. Microbial growth $\left(\log _{10} \mathrm{cfu} / \mathrm{g}\right)$ on fresh-cut lotus root slices stored in modified atmosphere packaging for $28 \mathrm{~d}$ at $4{ }^{\circ} \mathrm{C}$ (experiment 1). Data represent the mean \pm S.E. $(n=4)$. 


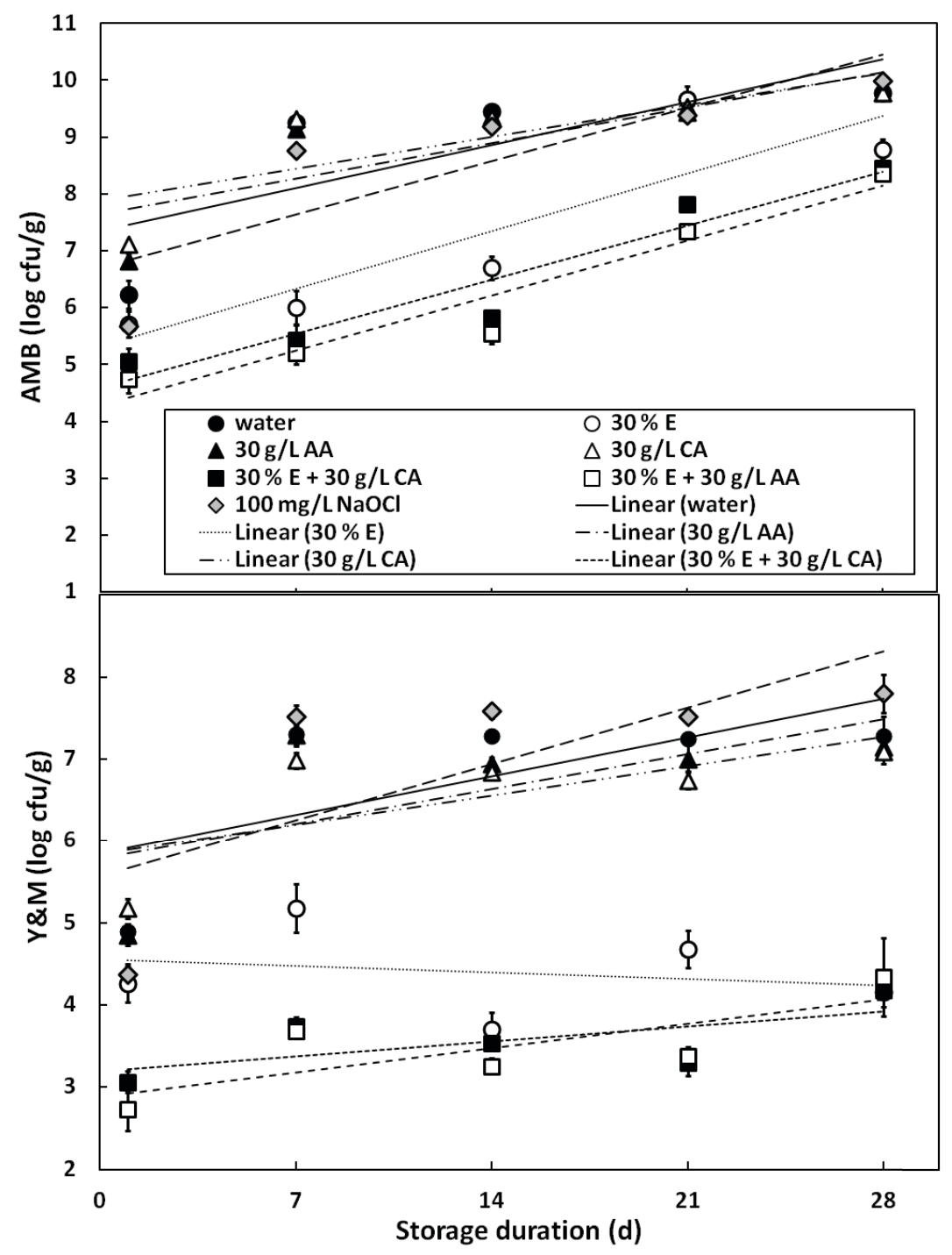

Treatments containing ethanol maintained significantly lower levels of microbes than treatments without ethanol throughout storage. The aerobic mesophilic bacterial counts (AMB) for $30 \% \mathrm{E}+30 \mathrm{~g} \mathrm{~L}^{-1} \mathrm{AA}$ treatment were significant lower than for $30 \% \mathrm{E}+30 \mathrm{~g} \mathrm{~L}^{-1} \mathrm{CA}$ treatment throughout storage time. However, Y\&M counts were not significantly different for these same 2 treatments. Both treatments had lower AMB and Y\&M counts than did $30 \% \mathrm{E}(P<$ 0. 05). The AMB for the 3 ethanol-containing treatments grew slowly remaining below $6.5 \log$ 
until after $14 \mathrm{~d}$, and then more rapidly from 14 to $21 \mathrm{~d}$, but AMB counts for treatments without ethanol increased rapidly during the first week reaching more than $8.5 \log$ by day 7 . The Y\&M counts for ethanol-containing treatments fluctuated within the range of $2.7 \log$ to $5.2 \log$, but counts for no-ethanol treatments sharply increased during the first $7 \mathrm{~d}$ and then remained over $6.8 \log$ until the end of storage. Combined, $30 \% \mathrm{E}$ and $30 \mathrm{~g} \mathrm{~L}^{-1} \mathrm{AA}$ or $30 \mathrm{~g} \mathrm{~L}^{-1} \mathrm{CA}$ have a bacteriostatic and fungistatic effect, but used separately, $30 \mathrm{~g} \mathrm{~L}^{-1} \mathrm{AA}$ and $30 \mathrm{~g} \mathrm{~L}^{-1} \mathrm{CA}$ have no inhibitory effect on microbes. Reduced effects on both AMB and Y\&M growth inhibition were observed for $30 \%$ E treatment $(P<0.05)$. Our observations that ethanol treatment inhibited microbial growth (Fig. 4 and Fig. 7) and limited decay are similar to the results reported by other researchers (Bai et al., 2004, 2011; Lurie et al., 2006; Plotto et al., 2006). Janisiewicz and Conway (2010) showed that a combination of ethanol dip and biocontrol was more effective to reduce decay of fresh produce than each individual treatment alone. Our research also found that a combination of ethanol and ascorbic acid or calcium ascorbate significantly improved inhibition of microbial growth compared to ethanol alone.

\subsection{Experiment 2: Effect of ethanol concentration}

The results from Experiment 1 indicated that two treatments, $30 \% \mathrm{E}+30 \mathrm{~g} \mathrm{~L}^{-1} \mathrm{AA}$ and 30 $\% \mathrm{E}+30 \mathrm{~g} \mathrm{~L}^{-1} \mathrm{CA}$, were more effective for inhibiting browning and maintaining quality of fresh-cut lotus root. These two treatments groups did not have significant differences for most analyses. Since the commercial browning agent, NatureSeal ${ }^{\circledR}$ containing the CA used in this experiment is a patented product, AA was chosen for further research. In order to find a lower effective concentration, five concentrations of ethanol: $5 \%, 10 \%, 20 \%, 25 \%$ and $30 \%$ were 
tested along with $30 \mathrm{~g} \mathrm{~L}^{-1} \mathrm{AA}$ to investigate their influence on package headspace gas composition, browning and microbial growth.

\subsubsection{Package headspace gas composition}

The $\mathrm{O}_{2}$ and $\mathrm{CO}_{2}$ partial pressures of fresh-cut lotus root slices treated with different concentrations of ethanol with $30 \mathrm{~g} \mathrm{~L}^{-1} \mathrm{AA}$ and stored for 7 and $14 \mathrm{~d}$ are shown in Fig. 5.

Fig. 5. Evolution of $\mathrm{O}_{2}$ and $\mathrm{CO}_{2}$ plotted as a function of storage time for fresh-cut lotus root

slices (experiment 2). Data represent the mean \pm S.E. $(n=4)$. Different upper case letters indicate significant differences between days within a treatment. Different lower case letters indicate significant differences among treatments within a day. 


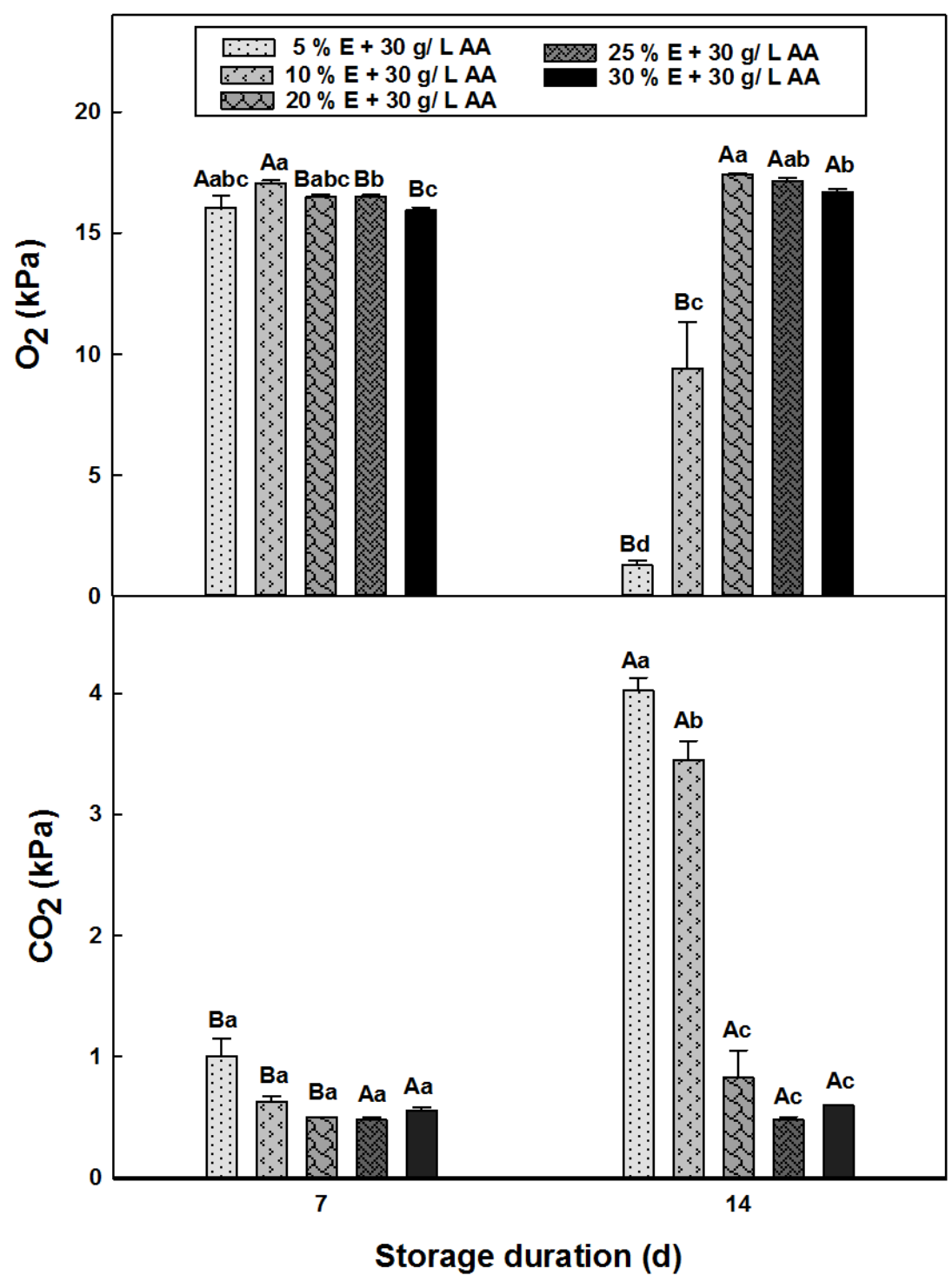

Packages of samples treated with higher concentrations of ethanol: 20,25 and $30 \%$ did not have significantly different $\mathrm{O}_{2}(16.70-17.42 \mathrm{kPa})$ or $\mathrm{CO}_{2}(0.47-0.82 \mathrm{kPa})$ partial pressures from each other and did not have a significant change in $\mathrm{O}_{2}$ or $\mathrm{CO}_{2}$ partial pressures between 7 and 14 $\mathrm{d}$, remaining significantly higher in $\mathrm{O}_{2}$ and lower in $\mathrm{CO}_{2}$ partial pressures at $14 \mathrm{~d}$ than packages of samples treated with 5 and $10 \%$ ethanol $(P<0.01)$.

\subsubsection{Color assessment}


The color measurements for fresh-cut lotus root slices stored at $4{ }^{\circ} \mathrm{C}$ are shown in Fig. 6 . 
Fig. 6. Color measurements of fresh-cut lotus root slices subjected to different ethanol concentrations, expressed as $L^{*}$ and hue angle values during storage at $4^{\circ} \mathrm{C}$ (experiment 2). Data represent the mean \pm S.E. $(n=3)$. Different upper case letters indicate significant differences among days within a treatment. Different lower case letters indicate significant differences among treatments within a day.

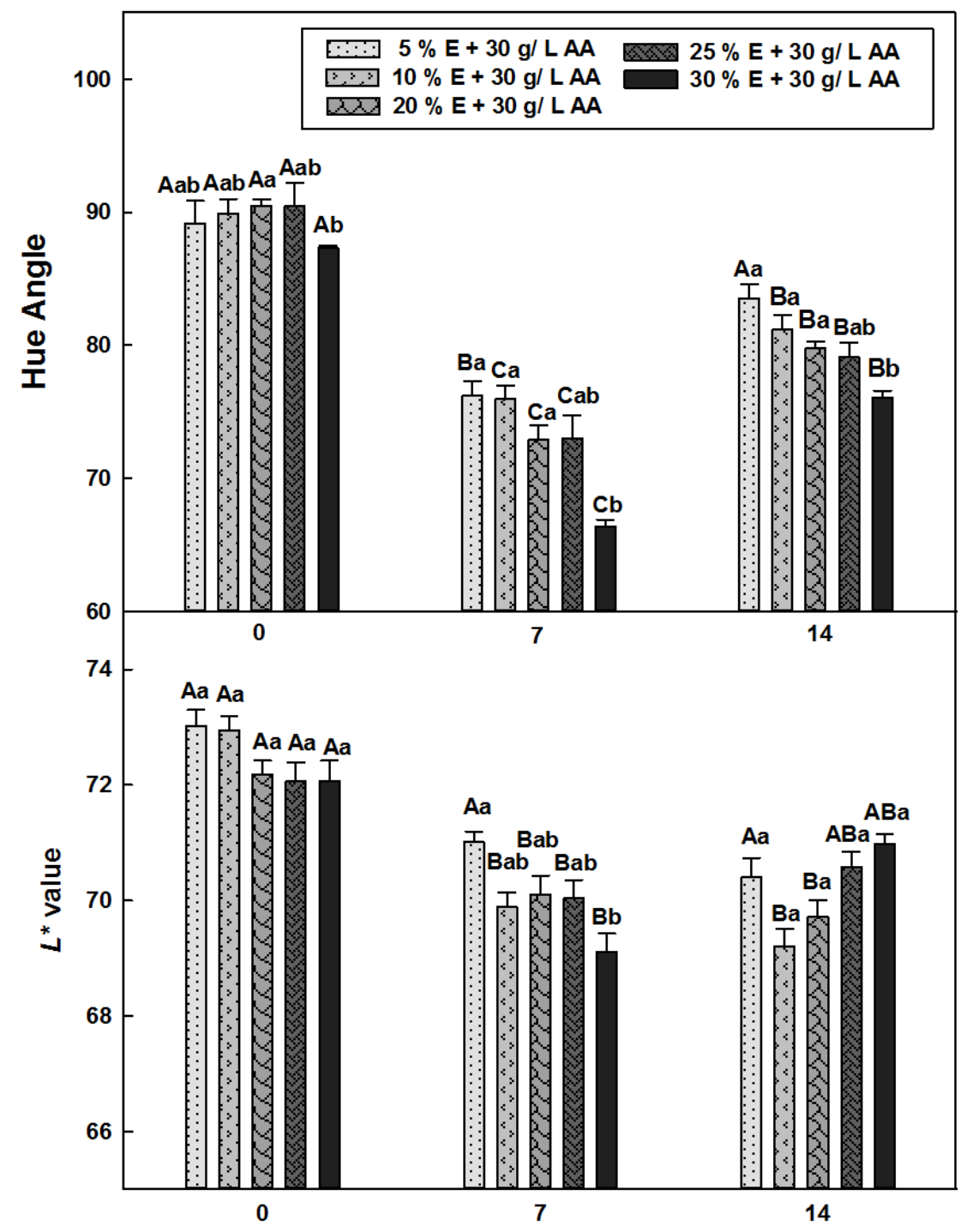


Lightness $\left(L^{*}\right)$ values declined significantly during the first $7 \mathrm{~d}$ of storage but were not significantly affected by ethanol concentration. Lightness values for all concentrations except 5 $\%$ ethanol, declined between day 0 and $7 \mathrm{~d}$, but did not change significantly from day 7 to day 14. $L^{*}$ values for $5 \%$ ethanol and $30 \%$ ethanol were significantly different on day 7 , but not on day 14. $L^{*}$ values for $5 \%$ ethanol were not significantly different from those for 10, 20 and $25 \%$ ethanol treatments on any evaluation day $(P<0.05)$. Also, $a^{*}$ values and hue angles for 5, 10, 20 and $25 \% \mathrm{E}+30 \mathrm{~g} \mathrm{~L}^{-1} \mathrm{AA}$ treatments were not significantly different on any evaluation day, but $a^{*}$ values were significantly higher and hue angles significantly lower for $30 \% \mathrm{E}+30 \mathrm{~g} \mathrm{~L}^{-1} \mathrm{AA}$ treatment than for 5,10 and $20 \% \mathrm{E}+30 \mathrm{~g} \mathrm{~L}^{-1} \mathrm{AA}$ treatments on days 7 and $14(P<0.05)$. Lower concentrations of ethanol therefore had less overall change in hue angle than higher concentrations during this experiment. It was noted that lotus root slices had more reddish color on day 7 than on day 14 which is consistent with the higher $a^{*}$ values and lower hue angles recorded on day 7 than on day 14 . However, this is an unexpected result and may be caused by inconsistent quality of raw material used. While lotus roots were relatively fresh at the start of experiment 1, they had been stored for several weeks prior to experiment 2.

\subsubsection{Microbial assays}

Figure 7 shows that microbial populations of $5 \% \mathrm{E}+30 \mathrm{~g} \mathrm{~L}^{-1} \mathrm{AA}$ and $10 \% \mathrm{E}+30 \mathrm{~g} \mathrm{~L}^{-1}$ AA treatment groups increased over storage time, those of $20 \% \mathrm{E}+30 \mathrm{~g} \mathrm{~L}^{-1} \mathrm{AA}$ and $25 \% \mathrm{E}+$ $3 \% 30 \mathrm{~g} \mathrm{~L}^{-1} \mathrm{AA}$ treatment groups did not change significantly over time and that of $30 \% \mathrm{E}+30$ $\mathrm{g} \mathrm{L}^{-1}$ AA actually decreased over time. Additionally, microbial populations were negatively correlated with alcohol concentration. 
Fig. 7. Microbial growth $\left(\log _{10} \mathrm{cfu} / \mathrm{g}\right)$ on fresh-cut lotus root slices stored in modified atmosphere packaging for $28 \mathrm{~d}$ at $4{ }^{\circ} \mathrm{C}$ (experiment 2). Data represent the mean \pm S.E. $(\mathrm{n}=4)$.

Different upper case letters indicate significant differences among days within a treatment.

Different lower case letters indicate significant differences among treatments within a day.

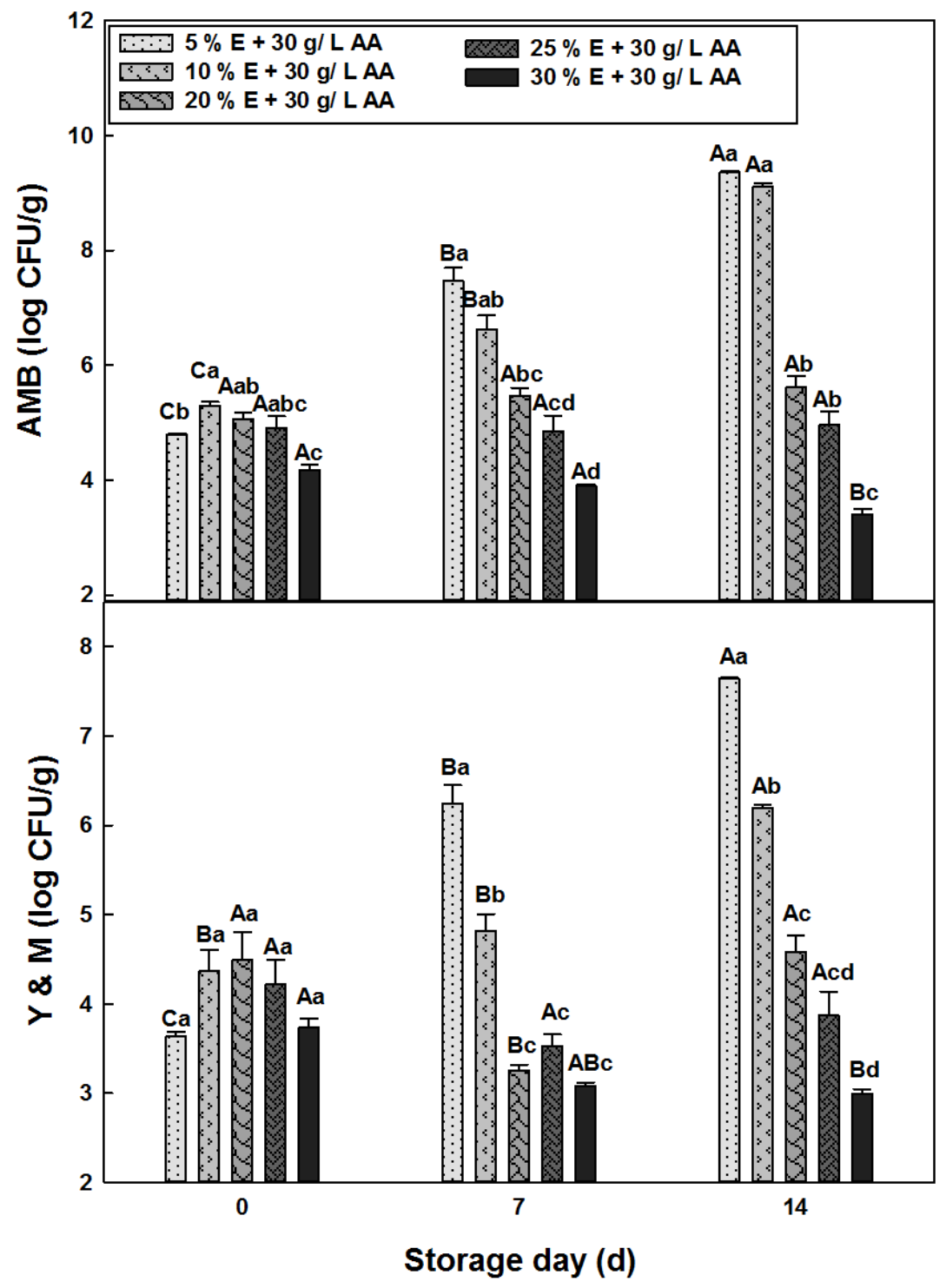

While AMB populations were significantly lower for $30 \% \mathrm{E}+30 \mathrm{~g} \mathrm{~L}^{-1} \mathrm{AA}$ than for $20 \% \mathrm{E}$ $+30 \mathrm{~g} \mathrm{~L}^{-1} \mathrm{AA}$ on day 7 and 14 or for $25 \% \mathrm{E}+30 \mathrm{~g} \mathrm{~L}^{-1} \mathrm{AA}$ on day 14 , there was no significant 
difference between AMB populations for $20 \% \mathrm{E}+30 \mathrm{~g} \mathrm{~L}^{-1} \mathrm{AA}$ and $25 \% \mathrm{E}+30 \mathrm{~g} \mathrm{~L}^{-1} \mathrm{AA}$ on day 7 and 14, or between $\mathrm{AMB}$ populations for $25 \% \mathrm{E}+30 \mathrm{~g} \mathrm{~L}^{-1} \mathrm{AA}$ and $30 \% \mathrm{E}+30 \mathrm{~g} \mathrm{~L}^{-1} \mathrm{AA}$ on day 7. There was no significant difference among Y\&M populations for 20,25 and $30 \% \mathrm{E}$ treatments on day 7. However, Y\&M populations were significantly lower for $30 \% \mathrm{E}+30 \mathrm{~g} \mathrm{~L}^{-1}$ AA than for $20 \% \mathrm{E}+30 \mathrm{~g} \mathrm{~L}^{-1}$ on day $14(P<0.05)$.

\section{Conclusion}

The majority of measured data in Experiment 1 followed a similar trend with treatments containing and lacking ethanol clearly divided into two groups. The treatment groups that lacked ethanol showed dramatic changes in $\mathrm{O}_{2}$ and $\mathrm{CO}_{2}$ gas, color, and microbial populations between day 0 and day 7 , while those that contained ethanol maintained stable values of the same parameters. A combination of ethanol and ascorbic acid or calcium ascorbate was more effective to inhibit microbial growth and improve quality of fresh-cut lotus root slices than ethanol alone. Understanding the mechanisms by which these combined treatments achieve these beneficial results will require further investigation.

Experiment 2 investigated the effect of different ethanol concentrations with added ascorbic acid to control microbes and maintain the quality of fresh-cut lotus root during cold storage. Consistent with most concentration gradient research (Wang et al., 2014), the microbial growth inhibition was proportional to the increase in ethanol concentration. Statistical analysis showed that although there were significant differences between $20 \%$ and $30 \%$ ethanol treatments with added ascorbic acid, these were small compared to the differences between treatment with and without ethanol. In conclusion, $20 \%-30 \%$ ethanol in combination with $30 \mathrm{~g} \mathrm{~L}^{-1}$ ascorbic acid and modified atmosphere packaging is an economic, practical and environmentally acceptable 
approach to inhibit browning and maintain quality of fresh-cut lotus root slices during cold storage.

\section{Acknowledgements}

This work is supported by USDA-NIFA Specialty Crop Research Initiative Grant Award No. 2010-51181-21230 and the International Science \& Technology Cooperation Program of China (2013DFA31450). Mention of trade names or commercial products in this publication is solely for the purpose of providing specific information and does not imply recommendation or endorsement by the USDA; USDA is an equal opportunity provider and employer.

\section{References}

Ahvenainen, R. (1996). New approaches in improving the shelf life of minimally processed fruit and vegetables. Trends in Food Science and Technology 7(6), 179-187.

Asoda, T., Terai, H., Kato, M., Suzuki, Y., (2009). Effects of postharvest ethanol vapor treatment on ethylene responsiveness in broccoli. Postharvest Biology and Technology 52, 216-220.

Bai, J. Baldwin, E. A. Fortuny, R. C. S. Mattheis, J. P. Stanley, R. Perera, C. \& Brecht, J. K. (2004). Effect of pretreatment of intact 'Gala' apple with ethanol vapor, heat, or 1Methylcyclopropene on quality and shelf life of fresh-cut slices. Journal of the American Society for Horticultural Science, 129(4), 583-593.

Bai, J. Plotto, A. Spotts, R. \& Rattanapanone, N. (2011). Ethanol vapor and saprophytic yeast treatments reduce decay and maintain quality of intact and fresh-cut sweet cherries. Postharvest Biology and Technology, 62(2), 204-212. 
Candir, E. Ozdemir, A. E. Kamiloglu, O. Soylu, E. M. Dilbaz, R. \& Ustun, D. (2012). Modified atmosphere packaging and ethanol vapor to control decay of 'Red Globe' table grapes during storage. Postharvest Biology and Technology, 63(1), 98-106.

Chatterjee, A. \& Pakrashi, S. C. (1991). The treatise on Indian medicinal plants. Vol 1 pp. 94-96. New Delhi, India: Publications and Information Directorate.

Chervin, C. Lavigne, D. \& Westercamp, P. (2009). Reduction of gray mold development in table grapes by preharvest sprays with ethanol and calcium chloride. Postharvest Biology and Technology, 54(2), 115-117.

Chervin, C. Westercamp, P. \& Monteils, G. (2005). Ethanol vapours limit Botrytis development over the postharvest life of table grapes. Postharvest Biology and Technology, 36(3), 319-322.

Dong, P. Kong, M. Yao, J. Zhang, Y. Liao, X. Hu, X. \& Zhang, Y. (2013). The effect of high hydrostatic pressure on the microbiological quality and physicochemical properties of lotus root during refrigerated storage. Innovative Food Science and Emerging Technologies, 19, 79-84.

Du, J. Fu, Y. \& Wang, N. (2009). Effects of aqueous chlorine dioxide treatment on browning of fresh-cut lotus root. LWT - Food Science and Technology, 42(2), 654-659.

Gutiérrez-Martínez, P. Osuna-López, S. G. Calderón-Santoyo, M. Cruz-Hernández, A. \& Bautista-Baños, S. (2012). Influence of ethanol and heat on disease control and quality in stored mango fruits. LWT - Food Science and Technology, 45(1), 20-27. 
Herppich, W. B. Huyskens-Keil, S. \& Hassenberg, K. (2014). Impact of ethanol treatment on physiological and microbiological properties of fresh white asparagus (Asparagus officinalis L.) spears. LWT - Food Science and Technology, 57(1), 156-164.

Hu, M. \& Skibsted, L. H. (2002). Antioxidative capacity of rhizome extract and rhizome knot extract of edible lotus (Nelumbo nuficera). Food Chemistry, 76(3), 327-333.

Hu, W. Jiang, A. Tian, M. Liu, C. \& Wang, Y. (2010). Effect of ethanol treatment on physiological and quality attributes of fresh-cut eggplant. Journal of the Science of Food and Agriculture, 90(8), 1323-1326.

Janisiewicz, W. J. \& Conway, W. S. (2010). Combining biological control with physical and chemical treatments to control fruit decay after harvest. Stewart Postharvest Review, 6(1), $1-16$.

Jiang, J. Jiang, L. Luo, H. \& Yu, Z. (2014). Establishment of a statistical model for browning of fresh-cut lotus root during storage. Postharvest Biology and Technology, 92, 164-171.

Karabulut, O. A. Gabler, F. M. Mansour, M. \& Smilanick, J. L. (2004). Postharvest ethanol and hot water treatments of table grapes to control gray mold. Postharvest Biology and Technology, 34, 169-177.

Kern, K.A., Pergo, E.M., Kagami, F.L., Arraes, L.S., Sert, M.A., Ishii-Iwamoto, E.L., (2009). The phytotoxic effect of exogenous ethanol on Euphorbia heterophylla L. Plant Physiology and Biochemistry 47, 1095-1101.

Kou, L. Luo, Y. Park, E. Turner, E. R. Barczak, A. \& Jurick, W. M. (2014a). Temperature abuse timing affects the rate of quality deterioration of commercially packaged ready-to-eat 
baby spinach. Part I: Sensory analysis and selected quality attributes. Postharvest Biology and Technology, 91, 96-103.

Kou, L. Yang, T. Luo, Y. Liu, X. Huang, L. \& Codling, E. (2014b). Pre-harvest calcium application increases biomass and delays senescence of broccoli microgreens. Postharvest Biology and Technology, 87(0), 70-78.

Lee, J.C. \& Eun, J.B. (1999). Inhibition of enzymatic browning in pre-cut lotus (Nelumbo nucifera $\mathrm{G}$.) roots by browning inhibitors and vacuum packaging. Acta Horticulture, (483), 349-356.

Lee, M. W. Cho, S. M. \& Lee, J. S. (2001). Anti-diabetic constituent from the node of lotus rhizome (Nelumbo nucifera Gaertn). Natural Product Sciences, 7(4), 107-109.

Lichter, A. Zutkhy, Y. Sonego, L. Dvir, O. Kaplunov, T. Sarig, P. \& Ben-Arie, R. (2002). Ethanol controls postharvest decay of table grapes. Postharvest Biology and Technology, 24(3), 301-308.

Liu, W. W. Qi, H. Y. Xu, B. H. Li, Y. Tian, X. B. Jiang, Y. Y. Xu, X. F. \& Lv, D. Q. (2012). Ethanol treatment inhibits internal ethylene concentrations and enhances ethyl ester production during storage of oriental sweet melons (Cucumis melo var. makuwa Makino). Postharvest Biology and Technology, 67, 75-83.

Lurie, S. Pesis, E. Gadiyeva, O. Feygenberg, O. Ben-Arie, R. Kaplunov, T. Zutahy, Y. \& Lichter, A. (2006). Modified ethanol atmosphere to control decay of table grapes during storage. Postharvest Biology and Technology, 42(3), 222-227. 
Mukherjee, D. Khatua, T. N. Venkatesh, P. Saha, B. P. \& Mukherjee, P. K. (2010).

Immunomodulatory potential of rhizome and seed extracts of Nelumbo nucifera Gaertn. Journal of Ethnopharmacology, 128(2), 490-494.

Mukherjee, P. K. Mukherjee, D. Maji, A. K. Rai, S. \& Heinrich, M. (2009). The sacred lotus (Nelumbo nucifera) - phytochemical and therapeutic profile. Journal of Pharmacy and Pharmacology, 61(4), 407-422.

Pesis, E. Faiman, D. \& Dori, S. (1998). Postharvest effects of acetaldehyde vapour on ripeningrelated enzyme activity in avocado fruit. Postharvest Biology and Technology, 13(3), $245-253$.

Pinto, R. Lichter, A. Danshin, A. \& Sela, S. (2006). The effect of an ethanol dip of table grapes on populations of Escherichia coli. Postharvest Biology and Technology, 39(3), 308-313.

Plotto, A. Bai, J. Narciso, J. A. Brecht, J. K. \& Baldwin, E. A. (2006). Ethanol vapor prior to processing extends fresh-cut mango storage by decreasing spoilage, but does not always delay ripening. Postharvest Biology and Technology, 39(2), 134-145.

Siomos, A. S. Gerasopoulos, D. Tsouvaltzis, P. \& Koukounaras, A. (2010). Effects of heat treatment on atmospheric composition and color of peeled white asparagus in modified atmosphere packaging. Innovative Food Science and Emerging Technologies, 11(1), $118-122$.

Son, J. Hyun, J. E. Lee, J. W. Lee, S. Y. \& Moon, B. (2015). Combined application of antibrowning, heat treatment and modified-atmosphere packaging to extend the shelf life of fresh-cut lotus root. Journal of Food Science, 80(6), C1178-1187. 
Sridhar, K. \& Bhat, R. (2007). Lotus-A potential nutraceutical source. Journal of Agricultural Technology, 3(1), 143-155.

Sun, Y. Zhang, W. Zeng, T. Nie, Q. Zhang, F. \& Zhu, L. (2015). Hydrogen sulfide inhibits enzymatic browning of fresh-cut lotus root slices by regulating phenolic metabolism. Food Chemistry, 177, 376-381.

Suzuki, Y. Kimura, T. Takahashi, D. \& Terai, H. (2005). Ultrastructural evidence for the inhibition of chloroplast-to-chromoplast conversion in broccoli floret sepals by ethanol vapor. Postharvest Biology and Technology, 35(3), 237-243.

Suzuki, Y. Uji, T. \& Terai, H. (2004). Inhibition of senescence in broccoli florets with ethanol vapor from alcohol powder. Postharvest Biology and Technology, 31(2), 177-182.

Tsuruta, Y. Nagao, K. Kai, S. Tsuge, K. Yoshimura, T. Koganemaru, K. \& Yanagita, T. (2011). Polyphenolic extract of lotus root (edible rhizome of Nelumbo nucifera) alleviates hepatic steatosis in obese diabetic $\mathrm{db} / \mathrm{db}$ mice. Lipids in Health and Disease, 10(1), 1.

USDA, Agricultural Research Service, Nutrient Data Laboratory. USDA National Nutrition Database for Standard Reference, Release 28. Version Current: September 2015. NDB No. 11254, 11255. Internet: https://ndb.nal.usda.gov/ Accessed February 16 ${ }^{\text {th }}, 2016$.

U.S. Food and Drug Administration. 1986. Sulfiting agents; revocation of GRAS status for use on fruits and vegetables intended to be served or sold raw to consumers. Fed. Regist. $51: 25021-25026$.

U.S. Food and Drug Administration. 2011. Sulfiting agents. 21 CFR Part 182, Subpart D. http:// www.fda.gov/downloads/Food/GuidanceComplianceRegulatoryInformation/ ComplianceEnforcement/ucm073305.pdf Accessed April 4, 2016. 
Wang, Q. Nie, X. \& Cantwell, M. (2014). Hot water and ethanol treatments can effectively inhibit the discoloration of fresh-cut sunchoke (Helianthus tuberosus L.) tubers. Postharvest Biology and Technology, 94(0), 49-57.

Wang, H., Feng, H., Luo, Y., (2004). Microbial reduction and storage quality of fresh-cut cilantro washed with acidic electrolyzed water and aqueous ozone. Food Research International $37,949-956$.

Xing, Y. Li, X. Xu, Q. Jiang, Y. Yun, J. \& Li, W. (2010). Effects of chitosan-based coating and modified atmosphere packaging (MAP) on browning and shelf life of fresh-cut lotus root (Nelumbo nucifera Gaerth). Innovative Food Science and Emerging Technologies, 11(4), 684-689.

Yang, D. Wang, Q. Ke, L. Jiang, J. \& Ying, T. (2007). Antioxidant activities of various extracts of lotus (Nelumbo nuficera Gaertn) rhizome. Asia Pacific Journal of Clinical Nutrition, 16, 158.

You, J. S. Lee, Y. J. Kim, K. S. Kim, S. H. \& Chang, K. J. (2014). Ethanol extract of lotus (Nelumbo nucifera) root exhibits an anti-adipogenic effect in human pre-adipocytes and anti-obesity and anti-oxidant effects in rats fed a high-fat diet. Nutrition Research, 34(3), $258-267$.

Zhang, S. Yu, Y. Xiao, C. Wang, X. \& Tian, Y. (2013). Effect of carbon monoxide on browning of fresh-cut lotus root slice in relation to phenolic metabolism. LWT - Food Science and Technology, 53(2), 555-559.

Zhao, X. Shen, J. Chang, K. J. \& Kim, S. H. (2014). Comparative analysis of antioxidant activity and functional components of the ethanol extract of lotus (Nelumbo nucifera) from 
various growing regions. Journal of Agricultural and Food Chemistry, 62(26), 6227-6235. 